\title{
Role of bacterial exopolymeric capsules in protection from deposit-feeder digestion
}

\author{
Craig J. Plante* \\ Dept of Biology, Grice Marine Laboratory, University of Charleston, 205 Fort Johnson Road, Charleston, \\ South Carolina 29412, USA
}

\begin{abstract}
Digestion of diverse strains of sedimentary bacteria by deposit feeders occurs at markedly disparate efficiencies, thus altering the composition of bacteria in feces and surrounding sediments. In an earlier study, I explored 2 potential mechanisms for resistance to lysis by digestive fluids of Arenicola marina (Polychaeta: Arenicolidae), cell wall ultrastructure and exopolymeric capsules. This correlative study revealed no relationship between encapsulation and lytic susceptibility across strains, whereas cell wall type (Gram-positive or -negative) was not independent of susceptibility, with Grampositive strains always resistant. In this study, I tested the importance of capsules within strains by comparing susceptibility after manipulation of capsule quantity using 2 techniques: (1) mechanical removal of capsules, and (2) harvest of cells through various growth phases as capsule thickness changes. We found that resistant strains remained resistant regardless of capsule quantity. Two of 3 strains that normally exhibit some susceptibility to lysis, Pseudomonas atlantica and SS-1, however, increased in their susceptibility with mechanical removal of capsules. Further, capsule quantity per cell varied throughout the growth cycle for these 2 strains, and lytic susceptibility varied concomitantly during logarithmic phase, in an inverse manner. Susceptibility of the third susceptible strain, IQ-2, remained unaltered with removal of capsules. This strain also exhibited dramatic change in capsule thickness with culture age, but lytic susceptibility was positively correlated to capsule mass per cell, in marked contrast to $P$. atlantica and SS-1. Although capsules can reduce the susceptibility of some bacterial strains, their presence does not convey protection from digestion in all strains, nor is encapsulation the only mechanism of resistance. One common feature for all these strains was that susceptibility to lysis declined after cultures reached stationary phase. Consequently, deposit feeding may impact physiological as well as taxonomic structure of bacterial assemblages in sediments.
\end{abstract}

KEY WORDS: Bacteriolysis · Capsules - Deposit feeders $\cdot$ Sedimentary bacteria

\section{INTRODUCTION}

Sedimentary bacteria are principal components of detrital food webs and their activities largely determine rates of biogeochemical cycling. Research effort has increased considerably during the last 2 decades, insofar as we now have a fair degree of predictive ability regarding the more quantitative aspects of the ecology of these bacteria, such as densities, biomass, and production rates (e.g., Cole et al. 1988, Deming \& Baross 1993). Significantly less is known about community composition and those factors that structure benthic microbial communities

·E-mail: plantec@cofc.edu
The abundance of sediment-feeding invertebrates, coupled with their high rates of sediment processing, suggests a potentially important role as grazers of bacteria. Indeed, bacterial numbers do decline with gut passage, yet a large fraction survive this digestive gantlet. Both field (e.g., Dobbs \& Guckert 1988, Duchene et al. 1988) and laboratory studies (Plante \& Shriver 1998a) have made clear that bacterial species differ in their resistance to digestion within the gut of a particular deposit feeder. For instance, using the lytic assay described below, Plante \& Shriver (1998a) showed that only a minority of sedimentary isolates were subject to digestion by Arenicola marina gut fluids, and that those strains differed in their sensitivities (see Fig. 1 in Plante \& Shriver 1998a). 

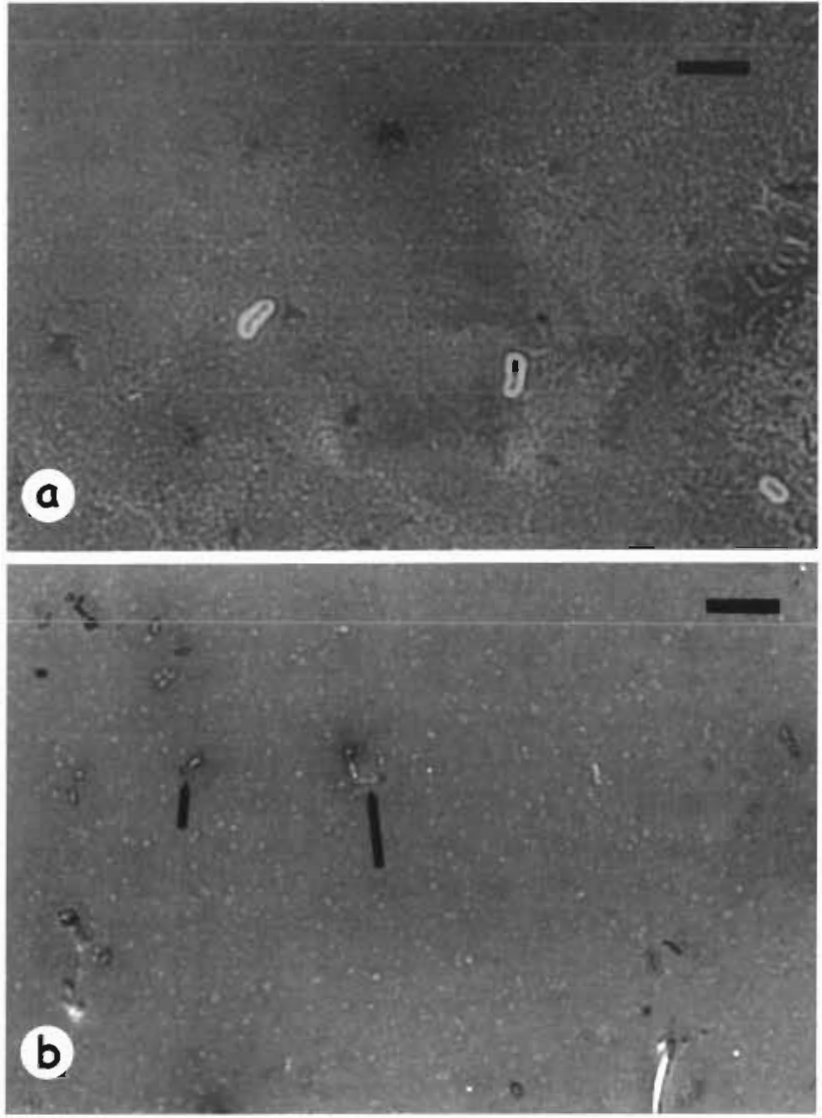

Fig. 1. A negative staining technique employing Congo Red and Maneval's stain was used to visualize capsules. (a) Thick capsules were observed for Pseudomonas atlantica cells at 24 h. (b) High-speed centrifugation was used to shear off capsules, producing 'naked' cells, e.g. for P. atlantica 24 h cultures. In color, cells are red and the background is blue-gray. Bar $=5 \mu \mathrm{m}$

Mechanisms for resistance to lysis have not been elucidated. There is some limited evidence that cell wall ultrastructure (King et al. 1991, Plante \& Mayer 1994, Plante \& Shriver 1998a) or extracellular secretions (Decho \& Lopez 1993) can be associated with greater resistance to digestion. In a correlative study, Plante \& Shriver (1998a) found no relationship between encapsulation and lytic susceptibility across strains, whereas cell wall type was not independent of susceptibility. To the contrary, numerous researchers have suggested a protective function of exopolymeric capsules against digestion by protozoans (Decho 1990. Gonzalez et al. 1990, Jürgens \& Güde 1994) and metazoans (Decho 1990). Further, one study has provided empirical evidence for capsular defense, in that digestive assimilation of encapsulated Pseudomonas atlantica by the deposit-feeding polychaete Streblospio benedicti was reduced as compared to non-capsuled mutants of the same species (Decho \& Lopez 1993).
In addition to taxonomic variation (e.g., Decho 1990, Plante \& Shriver 1998a), capsule quality and quantity can vary within strains according to activity level or physiological status (e.g., Sutherland 1977). For instance, Heissenberger et al. (1996) recently established that the majority of active bacterioplankton are encapsulated, whereas inactive cells are largely devoid of capsules. Consequently, grazing could not only effect change in the taxonomic character of bacterial assemblages, but also in their physiological compositions.

It appears that there may be multiple mechanisms by which bacteria resist digestion. Here we focus on extracellular polymeric secretions (EPS) production and test experimentally the null hypothesis that degree of encapsulation has no influenre on rate of digestive lysis within various bacterial strains.

\section{MATERIALS AND METHODS}

Model organisms. Two marine deposit feeders, Arenicola marina (Polychaeta: Arenicolidae) and Leptosynapta tenuis (Holothuroidea: Synaptidae), were collected from Passamaquoddy Bay, Maine, and Breach Inlet, South Carolina, respectively. Digestive fluids were extracted only from the midgut; dissection procedures and designations of various gut sections have been provided previously (Plante \& Mayer 1994). Midgut fluids from 1 to 4 animals were later pooled to provide $100-200 \mu$ samples to be used for lytic assays (see below).

A large number of distinct bacterial strains were isolated from intertidal sediments and deposit-feeder feces. Initial isolations were on Marine Broth 2216 agar medium (Difco Laboratories, Detroit, MI). Each environmental isolate was tested for biochemical, physiological and morphological characteristics (Tables 1 \& 2 in Plante \& Shriver 1998a). Four strains known to vary in capsule production, cell wall type or digestive susceptibility (SS-1, SS-13, SS-11, and IQ-2) were selected to be used in the present study. These strains have been tentatively assigned to the genera Pseudomonas, Bacillus, Moraxella, and Chromobacterium, respectively. The marine bacterium Pseudomonas atlantica, which has been well studied in the context of capsule production and function (e.g., Decho 1990, Decho \& Lopez 1993), was also employed.

Bacteriolytic assays. Lytic susceptibilities were compared using a modfication (Plante \& Mayer 1994) of the traditional lysozyme assay (e.g., McHenery \& Birkbeck 1982 , Morsky 1983). Bacteria were cultured in $40 \mathrm{ml}$ of filtered 2216 marine broth. Triplicate cultures of each strain were incubated on a shaker at $25^{\circ} \mathrm{C}$. Polypropylene micro-centrifuge tubes were filled with $1.5 \mathrm{ml}$ of 
each culture, then centrifuged at $5^{\circ} \mathrm{C}$ for $10 \mathrm{~min}$ at $2000 \times g$ to pelletize cells. Pellets were then washed twice with filter-sterilized seawater and repelleted. Immediately prior to analysis, pellets were resuspended in $66 \mathrm{mM}$ phosphate buffer ( $\mathrm{PB}$; potassium phosphate, monobasic, $\mathrm{pH} \mathrm{6.2),} \mathrm{then} \mathrm{transferred} \mathrm{to} \mathrm{dis-}$ posable $1 \mathrm{~cm}$ polystyrene cuvette tubes and further diluted to obtain absorbance values between 0.6 and 0.7 at $450 \mathrm{~nm}$. Although Arenicola marina gut fluids lyse bacteria under normal osmotic conditions (Plante \& Mayer 1994), cells were resuspended in PB to increase the sensitivity of the assay procedure. Use of this buffer in this assay does not alter the relative lytic susceptibilities of the various bacterial strains (author's unpubl. datal.

Following centrifugation $\left(2000 \times g, 10 \mathrm{~min}, 5^{\circ} \mathrm{C}\right)$ to remove particulates, undiluted gut fluid was added and mixed via pipet to bacterial resuspensions. For each bacterial strain, $5 \mu \mathrm{l}$ of digestive fluid (for both Arenicola marina and Leptosynapta tenuis) from a distinct pool was added to each of the replicate resuspensions. The spectrophotometer (Milton Roy Spectronic 601) was zeroed against PB; $5 \mu$ of PB was added to 3 additional bacterial suspensions to serve as controls. Lysis was followed turbidimetrically with $\mathrm{OD}_{450}$ (optical density) readings taken at $0,15,30,45,60,120,180$, and 300 s for each bacterial strain. Lytic rates were calculated using the linear portions of progress curves (Plante \& Mayer 1994). For each bacterial strain, a mean lytic rate for the PB control was calculated and subtracted from the gut-fluid rates.

Capsule observation and quantification. A negative staining technique employing Maneval's stain (Carolina Biological Supply Co., Burlington, NC) was used to test for capsule formation (Fig. 1, and see Plante \& Shriver 1998a). One loopful of culture suspension was mixed with 1 drop of $0.2 \mu \mathrm{m}$ filtered Congo Red ( $1 \%$ aqueous) on a clean glass slide, spread to cover the slide, and allowed to air dry. After completely dry, it was flooded with Maneval's modified stain. After at least $1 \mathrm{~min}$ the slide was gently washed with distilled water and blotted dry. Preparations were examined under phase-contrast at $1000 \times$ under oil immersion for capsule thickness, in addition to observations of cell morphology and cell integrity.

Capsules were removed via high-speed centrifugation and quantified using the alcian blue staining technique (Bayston \& Rodgers 1990). The use of alcian blue is an established histochemical technique for staining and preserving polysaccharides, glycosaminoglycans, and proteoglycans in bacterial samples (Brown et al. 1995). Low-speed centrifugation $(12000 \times \mathrm{g}, 15 \mathrm{~min}$, $4^{\circ} \mathrm{C}$ ) was first used to remove medium and exopolymeric slimes from cultures. The pelleted cells were resuspended in filtered $4 \mathrm{mM}$ EDTA solution (in sea- water). High-speed centrifugation $(25000 \times \mathrm{g}, 30 \mathrm{~min}$, $4^{\circ} \mathrm{C}$ ) was then used to shear off capsules from cells. After 3 rounds of resuspension and centrifugation, the supernatant was collected and frozen $\left(-20^{\circ} \mathrm{C}\right)$ until later analysis. One $\mathrm{ml}$ of supernatant was mixed with $4 \mathrm{ml}$ of alcian blue solution and incubated at room temperature for $1 \mathrm{~h}$. After centrifugation $(\sim 1500 \times \mathrm{g}$, $20 \mathrm{~min}, 4^{\circ} \mathrm{C}$ ) the supernatant was carefully aspirated by suction and replaced with $4 \mathrm{ml}$ absolute ethanol. After gentle mixing, the mixture was again centrifuged as above; the supernatant was then removed and replaced with $4 \mathrm{ml}$ of SDS $\left(100 \mathrm{~g} \mathrm{l}^{-1}\right.$ in $50 \mathrm{mM}$ sodium acetate, $\mathrm{pH}=5.8$ ). The mixture was then vortexed and the absorbance at $620 \mathrm{~nm}\left(\mathrm{OD}_{620}\right)$ recorded. A standard curve using chondroitin sulfate allowed for the conversion of $\mathrm{OD}_{620}$ values to $\mathrm{mg}^{-1}$ (Bayston \& Rogers 1990).

Expt 1. There is limited evidence that bacterial capsule quantity and quality varies with culture age (e.g., Decho 1990 and refererences therin), and also that lytic susceptibility may be a function of culture age (Plante \& Mayer 1994). We attempted to employ the natural variation in capsule quantity with age to determine whether capsule mass affected lytic susceptibility. We cultured various strains and measured optical density $\left(\mathrm{OD}_{450}\right)$, capsule quantity and lytic susceptibility to the digestive fluids of Arenicola marina and Leptosynapta tenuis through time.

ODs were converted to cell number using previously calculated regression equations. For each strain, ODs and total direct counts were recorded for triplicate cultures over time. Direct counts were made using epifluorescence microscopy and DAPI stain (Porter \& Feig 1980).

Expt 2. We compared the lytic susceptibility of capsuled and non-capsuled cells at 2 times, during both $\log$ and stationary phase. This experiment was performed using the gut fluids of Arenicola marina only. The 'naked' cells were produced by removing capsules using high-speed centrifugation, as described above.

To test for mechanical damage, pelleted, capsulefree cells were subsequently checked for viability by resuspending, diluting and plating onto 2216 marine agar. In a separate experiment, $P_{\text {seudomonas atlantica }}$ was used to more quantitatively test for undesired effects. Effects on culturability were assessed via quantitative plating before and after capsule removal. In addition, each strain was examined microscopically after capsule shearing in order to detect obvious damage.

Data analysis. One-way ANOVAs were employed to determine whether capsule mass and lytic susceptibility for the 5 bacterial strains varied with culture age. For each strain at each sampling time, lytic rates were compared to rates obtained with additions of PB (controls) using paired $t$-tests (1-tailed, log-transformed, 
$\mathrm{n}=3$ ). Likewise, $t$-tests were employed to test for significant capsule quantities at each sampling time. Pearson product-moment correlations were used to test for significant relationships between capsule quantity and lytic susceptibility. Susceptibility of encapsulated versus naked cells in Expt 2 was compared using paired $t$-tests. All statistical tests were performed using SYSTAT (version 5.2.1) for the Macintosh computer.

\section{RESULTS}

\section{Expt 1}

Four of 5 strains produced typical growth curves: SS-1, SS-11 and IQ-2 entered stationary phase between 30 and $40 \mathrm{~h}$, Pseudomonas atlantica at about $60 \mathrm{~h}$, while SS-13 cultures began to plateau then increased in $\mathrm{OD}_{450}$ between 36 and $80 \mathrm{~h}$ (Fig. 2a). Capsule quantity varied markedly among the 5 bacterial strains examined, with IQ-2 and P. atlantica producing the most capsule mass while SS-11 and SS-13 produced very little (Fig. 2b). Capsule mass varied significantly through time (both $\mathrm{ml}^{-1}$ and cell ${ }^{-1}$ ) for IQ-2, P. atlantica and SS-1 $(\mathrm{p}<0.0001, \mathrm{p}<0.0001$ and $\mathrm{p}=0.0003$, respectively, ANOVA; Fig. 2b). Total capsule mass tended to peak in late log or early stationary phase, with a gradual reduction as the cultures aged further (Fig. 2b). Capsule quantity per individual cell peaked earlier, however, and when examined in this way, capsule thickness clearly drops dramatically as cultures enter stationary phase (Fig. 3). The negatively stained slides provided qualitative corroboration of these differences among strains and changes in capsule amount through time.

Lytic susceptibility to Arenicola marina gut fluids also varied for these 3 strains with culture age $(p<0.001$ for IQ-2, $p=0.034$ for Pseudomonas atlantica and $p=0.039$ for SS-1, ANOVA). There appeared to be an inverse relationship between capsule mass cell ${ }^{-1}$ and lytic susceptibility for $P$. atlantica and SS-1 (although significant only for $P$. atlantica $r=-0.63, p=0.009$, $\mathrm{n}=15$; Fig. 3). IQ-2, on the other hand, showed a positive correlation $(\mathrm{r}=0.77, \mathrm{p}=0.008, \mathrm{n}=16)$. It should be noted, however, that cell size and shape changed dramatically (from long filaments of approximately $1 \times 20 \mu \mathrm{m}$ to rods of $1 \times 2 \mu \mathrm{m}$ ) for IQ- 2 with culture age, thereby affecting capsule mass cell ${ }^{-1}$. Strains SS-11 and SS-13 were not lysed by $A$. marina gut fluids at rates significantly different from $\mathrm{PB}$ controls

Lytic rates were always much lower with exposure to Leptosynapta tenuis versus Arenicola marina gut fluids (as has peviously been reported, see Plante \& Shriver 1998b). Lysis was rarely significantly greater than that
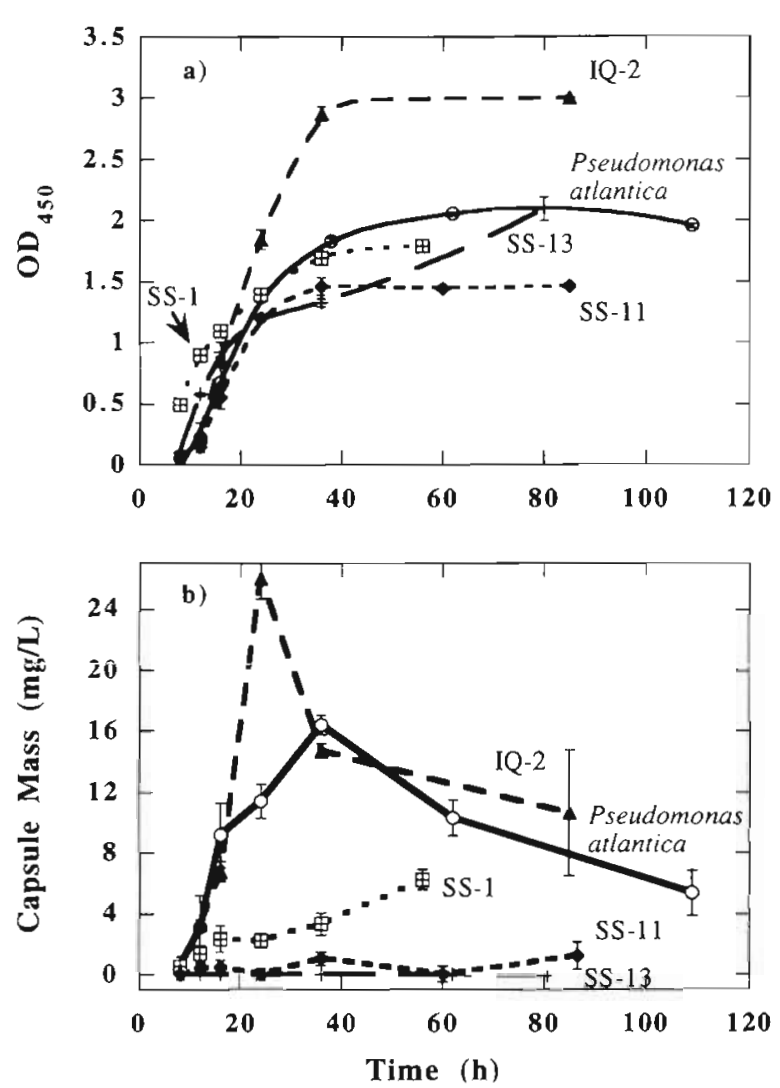

Fig. 2. (a) Mean ( \pm SEM) optical density and (b) total capsular mass of 5 bacterial strains at various culture ages. Capsule quantity was determined using alcian blue staining with chondroitin sulfate standards

for the control PB incubations for any of the 5 bacterial strains at any culture age when exposed to $L$. tenuis gut fluids (data not shown). Qualitatively, the results did seem to resemble those for $A$. marina, however, in that the only lytic rates that were (marginally) significant, the $62 \mathrm{~h}$ Pseudomonas atlantica culture $(\mathrm{p}=0.059$, $t$-test), SS-1 at $36 \mathrm{~h}(\mathrm{p}=0.021)$ and $56 \mathrm{~h}(\mathrm{p}=0.053)$, and IQ-2 at $16 \mathrm{~h}(p=0.070)$, coincided with those strain/culture age combinations that showed greatest susceptibility when incubated with $A$. marina gut fluids.

\section{Expt 2}

'Naked' cells were more susceptible to lysis than were encapsulated cells for both Pseudomonas atlantica and SS- 1 ( $\mathrm{p}=0.02$ and $\mathrm{p}=0.002$ for P. atlantica and SS-1 at 12 h, respectively, $t$-tests; Fig. $4 a$, b). The difference between susceptibility in naked and encapsulated cells, however, decreased with culture age (Fig. 4), so that by $109 \mathrm{~h}$ there was no difference in lytic susceptibility for naked versus encapsulated $P$, atlantica ( $p=0.70, t$-test). The gap for SS-1 also closed, but was 

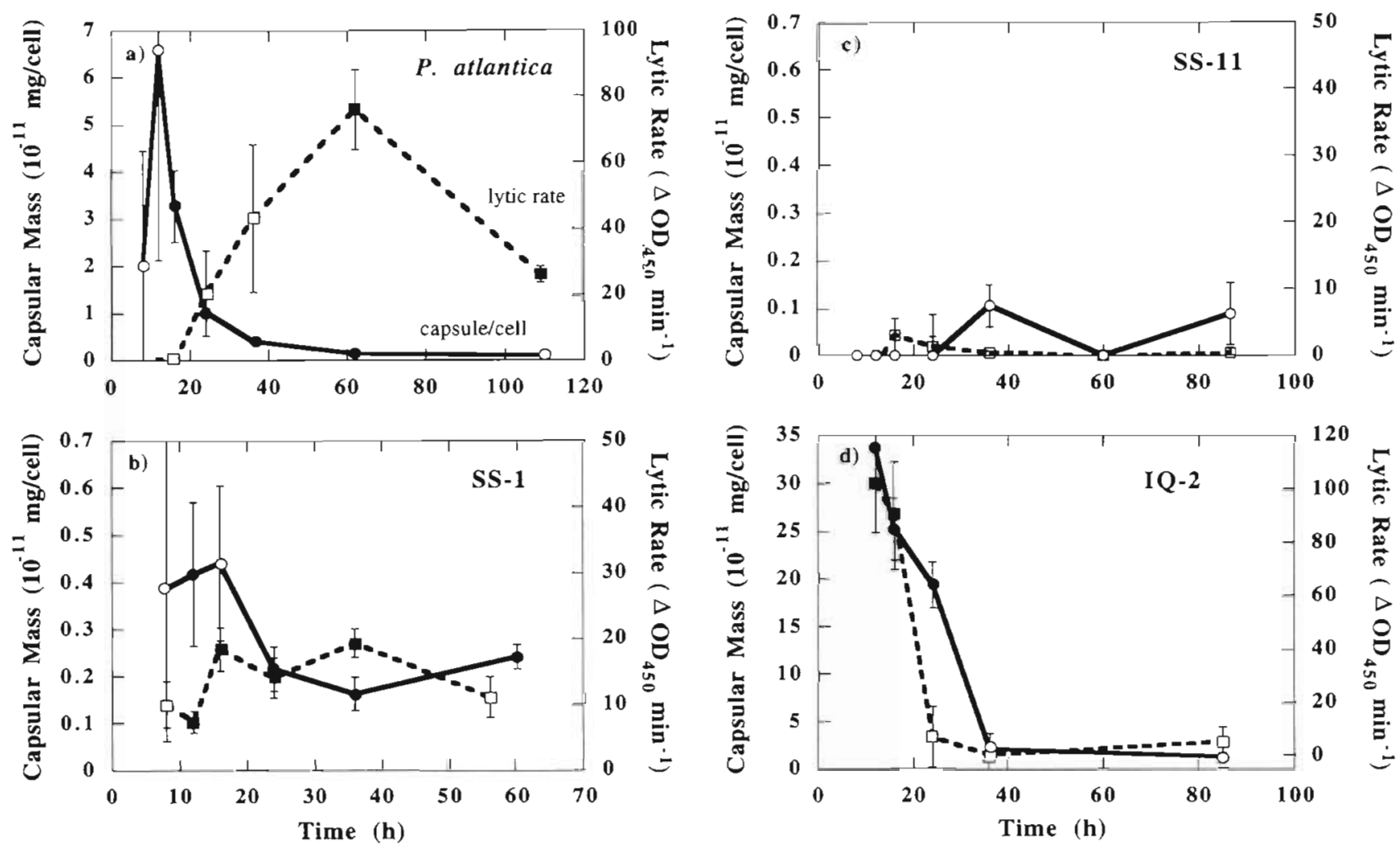

Fig. 3. Mean ( \pm SEM) lytic rate and capsule quantity (expressed as mass cell ${ }^{-1}$ ) through time for (a) Pseudomonas atlantica, (b) SS1. (c) SS-11, and (d) IQ-2. Data for SS-13 are not shown as lytic rate and capsule mass never differed significantly from controls. Optical densities were converted to bacterial numbers via regression for each strain; resulting densitıes were used to normalize total capsule mass $\mathrm{ml}^{-1}$ to mass cell ${ }^{-1}$. Filled symbols indicate values significantly different from phospate buffer controls $\{\alpha=0.05, t$-test $)$

still significantly different at $36 \mathrm{~h}(\mathrm{p}=0.032, t$-test). No such treatment effect was seen for IQ-2 for either log or stationary phase cultures $(\mathrm{p}>>0.05$ for both, $t$-tests; Fig. 4 d). Likewise, no effect was noted for SS-11 or SS13 (Fig. 4), as lysis was essentially zero, with or without centrifugation to shear off capsules.

Resuspended capsule-free cells were apparently undamaged, as they were culturable on 2216 agar and gave colony forming units (CFUs) comparable to those achieved prior to centrifugation. With Pseudomonas atlantica, quantitative plating revealed no differences in CFUs with centrifugation ( $p>0.10, t$-test). Visualization revealed no obvious cell rupture or distortions in any strain.

\section{DISCUSSION}

Exopolymeric capsules can provide protection against deposit-feeder digestion for at least a subset of sedimentary bacteria. Expt 1 revealed that capsule mass varied with culture age, and that lytic susceptibility varied concomitantly, so that more capsular mass was correlated with a greater level of protection for 2 of 5 strains. The results for Pseudomonas atlantica agree with those of Decho \& Lopez (1993), who showed using $P$. atlantica mutants that encapsulation afforded protection from digestion by the deposit-feeding polychaete Streblospio benedicti.

Numerous other physiological and biochemical changes, however, are also known to occur with culture age (Stolp \& Starr 1965, Ellwood \& Tempest 1972, Gilbert et al. 1990, Jürgens \& Güde 1994). The results of Expt 2 provide corroboration of the first experiment, in that they demonstrated the importance of capsules as opposed to some temporal co-variate; when capsules were mechanically sheared from cells, susceptibility increased for SS-1 and Pseudomonas atlantica. The value of this experiment relies heavily on the assumption that the effect of centrifugation is primarily that of capsule removal, without damage to the cells themselves. Previous comparisons of methods to remove EPS have shown high-speed centrifugation to be efficient and to result in minimal cell disruption (Brown \& Lester 1980). More specifically, Decho \& Moriarty (1990) monitored levels of intracellular enzymes re- 

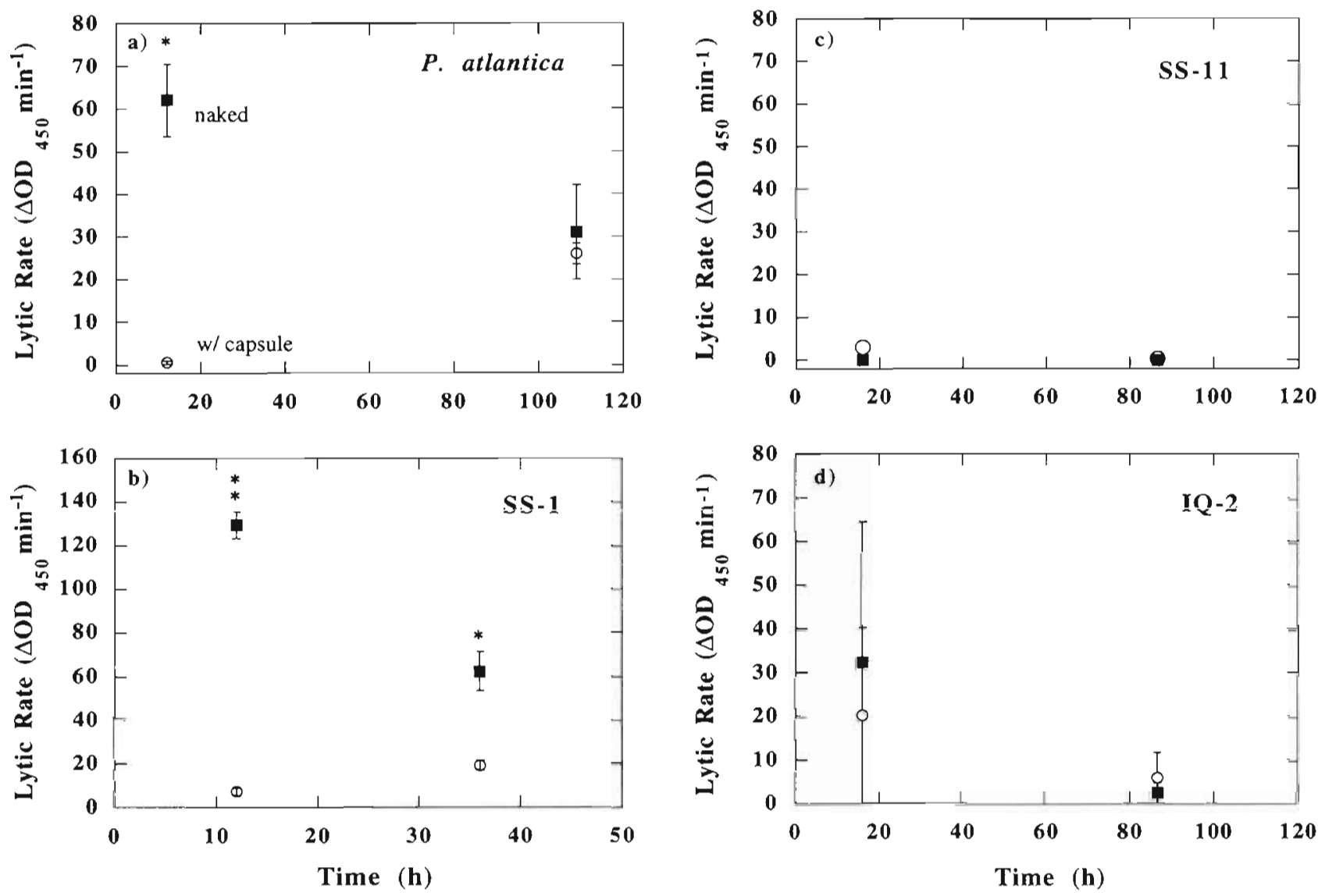

Fig. 4. Removal of capsules resulted in increased lytic susceptibility ( \pm SEM) for (a) Pseudomonas atlantica and (b) SS-1, especially for young cultures. No change was noted for (c) SS-11, (d) IQ-2 or SS-13 (data not shown). "Significant differences between naked and encapsulated cells at a given culture age $(\cdot p<0.05, \cdots p<0.005$; $t$-tests $)$

leased by this procedure and found minimal cell disruption for a marine pseudomonad. Furthermore, in the present experiments, when the now capsule-free $P$. atlantica pelleted cells were resuspended, CFUs on 2216 agar demonstrated that culturability was unaffected by the centrifugation process.

Bacterial exopolymers serve diverse ecological roles (e.g., see review in Decho 1990), but a central role is that of protection. Exopolymeric secretions have previously been shown to protect various bacterial types from toxic compounds (Christensen et al. 1985), antimicrobial agents (Costerton \& Cheng 1975, Brown et al. 1995), antibodies (Dudman 1977), phages (Bayer \& Bayer 1981), and protozoan grazers (Jürgens \& Güde $1990,1994)$. In the majority of these studies, the nature of the extracellular material, i.e. capsules versus loosely associated slimes, was not distinguished. It has been proposed, however, that capsular secretions likely provide a better chemical barrier than slimes, given the more tightly wound polysaccharide fibrils in capsules (e.g., Decho 1990 and references therein). It is not surprising then that capsules might provide defense against the digestive secretions of deposit feeders, given the protection afforded against the disparate enzymes and biotic defense mechanisms noted above. Resistance against at least some enzymes is prerequisite for the carbohydrate fibrils forming these bacterial capsules, as they must resist the bacterium's own ectoenzymes embedded within the capsule (Stoderegger \& Herndl 1998). Further, bacterial symbionts have been shown to employ capsules as protective barriers against host digestive agents, e.g., in the cow rumen (Costerton et al. 1974).

Although these results demonstrate the protective role of capsules within 2 bacterial strains, it is clear that other mechanisms of protection against digestion exist. In fact, in a previous study we found no correlation between the ability to form capsules and digestive resistance across a variety of environmental strains, whereas cell wall structure was correlated with resistance (i.e., Gram-positive cells were always resistant) (Plante \& Shriver 1998a). The present study also makes this point clear. Although, overall, susceptibility increased for Pseudomonas atlantica and SS-1 with 
declining capsule mass, susceptibility of naked cells decreased as the cultures aged. Thus, some characteristic apparently unrelated to extracellular secretions changed so as to confer some measure of resistance as the cultures aged. It is well known, for instance, that cell wall structure changes as cells move from active growth into stationary phase (Stolp \& Starr 1965, Ellwood \& Tempest 1972, Jügens \& Güde 1994). This study also further illustrates that encapsulation does not guarantee protection from lysis; IQ-2 produced by far the most capsular material, yet was the most susceptible to lysis.

Although removal of capsules or the use of EPS-deficient mutants are straightforward means of addressing the question of whether encapsulation provides protection, these do not allow for the examination of the effects of culture age and physiological status. Results from Expt 1 suggest that digestive susceptibility should vary in situ, within a given bacterial strain, based on the physiological status of individual cells. For Pseudomonas atlantica and SS-1 greater resistance was observed during mid-and late-log phases when capsule mass/cell was at a maximum (Fig. 3). This relationship is complex, however, in that it varied among strains. The opposite pattern, decreasing lytic rate with less capsule mass, was observed for IQ-2, while SS-11 and SS-13 were resistant regardless of capsule quantity. What is more clear, however, is that digestive susceptibility tends to drop sharply after cultures enter the stationary phase.

As aquatic environments are subject to spatial and temporal nutrient fluxes, it is likely that individual bacteria frequently enter and exit stages of nutrient stress. With prolonged deficiency, most cells will enter a state of metabolic inactivity (Roszak \& Colwell 1987), a condition similar to that of stationary phase in batch culture. Capsule mass might then be expected to decrease, as was observed in our in vitro experiments. This relationship between cellular activity and the presence of capsules has recently been documented for marine bacterioplankton in situ (Heissenberger et al. 1996, Stoderegger \& Herndl 1998). With respect only to capsule quantity, physiologically 'old' cells should then be more susceptible to grazing. However, in our experiments other changes (perhaps in cell wall composition) more than compensate for the decline in capsule mass so that susceptibility is actually reduced in stationary phase, with the caveat that some strains (e.g., Pseudomonas atlantica) are also relatively resistant in early log phase.

In agreement with these results, the available data suggest that grazing by protozoa preferentially removes active cells (Sherr et al. 1992, del Giorgio \& Scarborough 1995, del Giorgio et al. 1996). Sizeselective grazing, not changes in bacterial resistance, is the proposed mechanism for protozoan removal of a disproportionately larger fraction of active cells (Gonzalez et al. 1990, Bird \& Kalff 1993). The situation in sediments is fundamentally different with respect to bacterivory, however, in that most bacteria are particle-associated (DeFlaun \& Mayer 1983, Ellery \& Schleyer 1984, Epstein \& Rossel 1995). Numerous types of protozoan bacterivores have been shown to be limited in their ability to graze attached bacteria (e.g., Caron 1987). Whereas protozoan grazers have been demonstrated to be the most important source of bacterial mortality in the water column (Jürgens \& Güde 1994, and references therein), it has not so far been established that they play a similarly dominant role in sediments (Kemp 1990, Epstein \& Shiaris 1992). For these reasons, it is likely that metazoan grazing plays a relatively more important role in cropping bacterial production in sediments. It can be speculated that where less selective grazers (e.g., deposit feeders, and perhaps metazoans in general) dominate, 'selection' occurs in the gut, at the stage of digestion, as opposed to the point of ingestion, but that the end results are rather similar in that the number of active cells in the habitat should be reduced relative to total bacteria. Consequently, grazing could not only affect change in the taxonomic composition of bacterial assemblages, but also in their physiological compositions.

The above discussion must be viewed with caution since our experiments were performed in batch culture, and neglected any influence of biofilms. Biofilms have repeatedly been shown to play a major ecological role in sediments (Decho 1990, and references therein, Decho \& Lopez 1993). The complex nature of a biofilm certainly is not well reproduced by capsules produced by single bacterial strains in broth culture. They are not unrelated, however, as biofilms consist of encapsulated cells embedded in more amorphous extracellular secretions (Decho 1990, Brown et al. 1995). Moreover, much of the resistance of biofilms to antimicrobial agents and other insults may in fact be related to the disparate physiological states of the bacteria within (Xu et al. 1998).

This study has demonstrated that bacterial capsules can protect cells from enzymatic digestion, but that this protection is dependent upon the physiological status of the bacterium. This dependence may result in 'selection' by metazoans that may be quite unlike selection by protozoan grazers and bacteriophages. Profitable future work would examine how bacteriolysis in sediments by phages and protozoan and metazoan grazers is influenced by the victim's physiological state. Ultimately, this type of work must include the difficulties of examining these processes within intact biofilms and in association with particulates. 
Acknowledgements. Major financial support was provided by NSF grant OCE 95-04505. A College of Charleston Research and Development grant provided for additional resources. Direct counts for conversion of optical densities to cell numbers were performed by L. Flinn. Helpful comments were provided by S. Hymel, S. Wilde, F. Dobbs and 2 anonymous reviewers. This is contribution no. 173 of the Grice Marine Laboratory, University of Charleston, South Carolina.

\section{LITERATURE CITED}

Bayer ME, Bayer MH (1981) Fast response of bacterial membranes to virus adsorption: a fluorescence study. Proc Natl Acad Sci USA 78:5618-5622

Bayston R, Rodgers J (1990) Production of extra-cellular slime by Staphylococcus epidermis during stationary phase of growth: its association with adherence to implantable devices. J Clin Pathol 43:866-870

Bird DF, Kalff J (1993) Protozoan grazing and size-activity structure in limnetic bacterial communities. Can J Fish Aquat Sci 50:370-380

Brown MJ, Lester JN (1980) Comparison of bacterial extracellular polymer extraction methods. Appl Environ Microbiol 40:179--185

Brown ML, Aldrich HC, Gauthier JJ (1995) Relationship between glycocalyx and providone-iodine resistance in Pseudomonas aeruginosa (ATCC 27853) biofilms. Appl Environ Microbiol 61:187-193

Caron DA (1987) Grazing of attached bacteria by heterotrophic microflagellates. Microb Ecol 13:203-218

Christensen BE, Kjosbakken J, Smidsrod O (1985) Partial chemical and physical characterization of two extracellular polysaccharides produced by marine periphytic Pseudomonas sp. strain NCMB 2021. Appl Environ Microbiol 50: $837-845$

Cole JJ, Findlay S, Pace ML (1988) Bacterial production in fresh and saltwater systems: a cross-system overview. Mar Ecol Prog Ser 43:1-10

Costerton JW, Cheng KJ (1975) The role of the bacterial cell envelope in antibiotic resistance. J Antimicrob Chemother $1: 363-377$

Costerton JW, Damgaard HN, Cheng KJ (1974) Cell envelope morphology of rumen bacteria. J Bacteriol 118:1132-1143

Decho AW (1990) Microbial exopolymer secretions in ocean environments: their role(s) in food webs and marine processes. Oceanogr Mar Biol Annu Rev 28:73-153

Decho AW, Lopez GR (1993) Exopolymer microenvironments of microbial flora: multiple and interactive effects on trophic relationships. Limnol Oceanogr 38:1633-1645

Decho AW, Moriarty DJW (1990) Bacterial exopolymer utilization by a harpacticoid copepod: a methodology and results. Limnol Oceanogr 35:1039-1049

DeFlaun MF, Mayer LM (1983) Relationships between bacteria and grain surfaces in intertidal sediments. Limnol Oceanogr 28:873-881

del Giorgio PA, Scarborough G (1995) Increase in the production of metabolically active bacteria along gradients of enrichment in freshwater and marine plankton: implications for estimates of bacterial growth and production rates. J Plankton Res 17:1905-1924

del Giorgio PA, Gasol JM, Vaque D, Mura P, Agusti S, Duarte CM (1996) Bacterioplankton community structure: protists control net production and the proportion of active bacteria in a coastal marine community. Limnol Oceanogr 41 . $1169-1179$
Deming JW, Baross JA (1993) The early diagenesis of organic matter. In: Engel M, Macko S (eds) Organic geochemistry. Plenum Press, New York, p 119-144

Dobbs FC, Guckert JB (1988) Microbial food resources of the macrofaunal-deposit feeder Ptychodera bahamensis (Hemichordata: Enteropneusta). Mar Ecol Prog Ser 45 $127-136$

Duchene JC, Imbaud P, Delille D (1988) Associated bacterial microflora of a subantarctic polychaete worm Thelepus setosus. Arch Hydrobiol 112:221-231

Dudman WF (1977) The role of surface polysaccharides in natural environments. In: Sutherland IW (ed) Surface carbohydrates of the prokaryote cell. Academic Press, New York, p 357-414

Ellery WN, Schleyer MH (1984) Comparison of homogenization and ultrasonication as techniques in extracting attached sedimentary bacteria. Mar Ecol Prog Ser 15: $247-250$

Ellwood DC, Tempest DW (1972) Effects of environment on bacterial wall content and composition. Adv Microb Phys 7:83-117

Epstein SS, Rossel J (1995) Enumeration of sandy sediment bacteria: search for an optimal protocol. Mar Ecol Prog Ser 117:289-298

Epstein SS, Shiaris Mp (1992) Size-selective grazing of coastal bacterioplankton by natural assemblages of pigmented flagellates, colorless flagellates, and ciliates. Microb Ecol 23:211-225

Gilbert P, Collier PJ, Brown MRW (1990) Influence of growth rate on susceptibility to antimicrobial agents: biofilms, cell cycle, dormancy, and stringent response. Antimicrob Agents Chemother 34:1865-1868

Gonzalez JM, Iriberri J, Egea L, Barcina I (1990) Differential rates of digestion of bacteria by natural assemblages of of estuarine flagellates and ciliates. Appl Environ Microbiol 56:583-589

Heissenberger A, Leppard GG, Herndl GJ (1996) Relationship between the intracellular integrity and the morphology of the capsular envelope in attached and free-living marine bacteria. Appl Environ Microbiol 62:4521-4528

Jürgens K, Güde H (1990) Incorporation and release of phosphorus by planktonic bacteria and phagotrophic flagellates. Mar Ecol Prog Ser 59:271-284

Jürgens $K$, Güde $H$ (1994) The potential importance of grazing-resistant bacteria in planktonic systems. Mar Ecol Prog Ser 112:169-188

Kemp PF (1990) The fate of benthic bacterial production. Rev Aquat Sci 2:109-124

King $\mathrm{CH}_{4}$, Sanders RW, Schotts EB, Porter KG (1991) Differential survival of bacteria ingested by zooplankton from a stratified eutrophic lake. Limnol Oceanogr 36:829-845

McHenery JG, Birkbeck TH (1982) Characterization of the lysozyme of Mytilus edulis (L.). Comp Biochem Physiol 71B: $583-589$

Morsky P (1983) Turbidimetric determination of lysozyme with Micrococcus lysodeikticus cells: re-examination of reactiob conditions. Anal Biochem 128:77-85

Plante CJ, Mayer LM (1994) Distribution and efficiency of bacteriolysis in the gut of Arenicola marina and three additional deposit feeders. Mar Ecol Prog Ser 109:183-194

Plante CJ, Shriver A (1998a) Differential lysis of sedimentary bacteria by Arenicola marina: examination of cell wall structure and exopolymeric capsules as correlates. J Exp Mar Biol Ecol 229:35-52

Plante CJ, Shriver A (1998b) Patterns of differential digestion of bacteria in deposit feeders: a test of resource partitioning. Mar Ecol Prog Ser 163:253-258 
Porter KG, Feig YS (1980) The use of DAPI for identifying and counting aquatic microflora. Limnol Oceanogr 25:943-948

Roszak DB, Colwell RR (1987) Survival strategies of bacteria in the natural environment. Microb Rev 51:365-379

Sherr BF, Sherr EB, McDaniel J (1992) Effect of protistan grazing on the frequency of dividing cells in bacterioplankton assemblages. Appl Environ Microbiol 58:2381-2385

Stoderegger K, Herndl GJ (1998) Production and release of bacterial capsular material and its subsequent utilization by marine bacterioplankton. Limnol Oceanogr 43:877-884

Editorial responsibility: John Dolan,

Edgewater, Maryland, USA
Stolp H, Starr MP (1965) Bacteriolysis. Annu Rev Microbiol 19:79-104

Sutherland IW (1977) Bacterial exopolysaccharides - their nature and production. In: Sutherland IW (ed) Surface carbohydrates of the prokaryotic cell. Academic Press, New York, p 27-96

Xu KD, Stewart PS, Xia F, Huang CT, McFeters GA (1998) Spatial physiological heterogeneity in Pseudomonas aeruginosa biofilm is determined by oxygen availability. Appl Environ Microbiol 64:4035-4039

Submitted: September 28, 1999; Accepted: December 23, 1999 Proofs received from author(s): May 17, 2000 